protests or riots in the near future. That possibility will not be elaborated here.

The middle-way, or the most probable scenario, is that a small-scale antiMuslim protest breaks out soon and the authorities get involved before it is too late. However, enforcing the rule of law (whatever is meant by that) alone will not be a long-term solution because Myanmar is now democratising with a freer press and a civil society that is politically and socially more active. Only when the larger society at least accepts the legal legitimacy of the presence of Muslims (both Rohingya and non-Rohingya) within Myanmar, will the issue be permanently solved. This will take much time and dedicated effort on all sides.

\title{
Note
}

* Salvador del Souza, a Doctoral candidate at a major Australian university pursuing research on S.E. Asian societies and conflict resolution.

\section{Why Pursue Negotiations with the Taliban?}

\section{Abdul-Qayum Mohmand}

Despite the unprecedented international financial aid and military support to the government of Afghanistan, the scaled-up military presence of the United States and the variety of US and ISAF (International Security Assistance Force) tactics used in the ongoing effort to defeat the resistance and establish peace, security and the rule of law, the situation in Afghanistan has deteriorated. The resistance has grown, war and insurgency in Afghanistan have intensified, and the Taliban have expanded their activities, becoming a countrywide movement with territory gained in the north and west. Conversely, the United States is facing great economic challenges both at home and abroad, and there is pressure from Congress and the American public on President Barak Obama to bring American men and women deployed in Afghanistan back home.

The Pashtun insurgency, which is composed of multiple, seemingly infinite, local groups, is fed by what is perceived by the Pashtun people as a continued and sustained assault, going back centuries, on Pashtun land, culture, tradition and religion by internal and external enemies. The US and NATO presence and operations in Pashtun valleys and villages, as well as Afghan army and police that are led and composed of non-Pashtun soldiers and police, provide an occupation force against which the insurgency is justified. ${ }^{1}$ The intensity of resistance varies from province to province, being the strongest in the south and east, yet resistance is expanding and has swept through many areas throughout Afghanistan. 
The thinking of US and NATO decision makers seems to be that if the Pashtuns' political and economic capacities are weakened or diminished, resistance to the international occupying forces will also be weakened and will eventually diminish. However, eleven years of undiminished and mounting violence in Afghanistan have only proven the opposite. The more pressure applied and pain inflicted, the more their homes and farms are destroyed and their women, children and men killed, the more Pashtuns are encouraged to lend a supporting hand to the resistance movement. Therefore, to bring an end to the war- to bring about peace, stability, and sustainable political and economic development and improve the living standards of the Afghan people - the answer is not to prolong the war and try to weaken Pashtun capacities. Rather, the United States and its allies need to bring an end to the fighting and reach a political compromise with the Resistance. They should refrain from military aggression that only feeds the mounting political and social outrage. The United States along with its partners in the international community should focus its efforts on achieving a deeper understanding of Afghanistan's unique and resilient social values and political culture, and on meeting urgent economic needs. Failure to recognise such realities can only lead to the deterioration and eventual demise of the influence of the United States in Afghanistan.

The hostile feelings aroused by the continuing US war strategy amongst the Afghans, and particularly Pashtuns, feed popular support for the Taliban. The Taliban are not only supported by the rank and file, but increasingly also by the common man and the intelligentsia in the country and among expatriates. The war in Afghanistan has gone from a conflict between the Taliban and the US-led ISAF into a bitter struggle against foreign occupation and for survival and equitable representation. Mathew Hoh confirms this in stating that "the bulk of the insurgency fights not for the white banner of the Taliban, but rather against the presence of foreign soldiers and taxes imposed by an unrepresentative government in Kabul." ${ }^{2}$ This has transformed the Taliban movement from a purely military fighting force into much more of a politically conscious opposition resistance movement. The Taliban are no longer merely a religiousstudent militia organisation obsessed with applying their strict interpretation of the Shari'ah, having opted for a return to power as a party open to inclusion and pluralism, respect and protection of citizen rights, and acceptance of education for both genders. This is a sea-change with possibly enduring ramifications for the future political system in Afghanistan.

An environment of trust must first be created in which Taliban leaders can feel secure enough to take part in negotiations. The Taliban leaders must feel convinced that engaging in negotiations and revealing their identity will not lead to their harassment and arrest. Once the scrutiny of those affiliated with the 
Taliban living in Kabul and other key urban areas of the country ends, the Taliban in outlying areas and fighting in the front lines may themselves come to view their adversary, the United States, as being seriously and honestly interested in negotiating agreement through compromise.

At that point, negotiations could proceed in three stages. First, direct negotiation between the US and the Taliban could aim at reconciliation with patient efforts pursued to promote a sustained dialogue. In this initial stage both the United States with its allies and the Taliban should seek agreement on a cease-fire, with the US releasing Taliban prisoners from Guantanamo, Bagram, and other prison or secret 'rendition' facilities and removing names of Taliban leaders from any blacklist or watch-list. An agreement between the two sides could be reached through negotiation, and with the outcome approved by the Taliban leadership, especially Mullah Mohammad Omar, the rank and file would follow.

After this, negotiations could move to the second stage, which should include the United States, the Taliban, the Afghan government, and other key actors such as Gulbuddin Hekmatyar and the Haqqani Group (if the latter were not included among the Taliban interlocutors in the first stages). Since this stage involves intricate negotiating among Afghans, a non-partisan independent peace team needs to be put in place to arbitrate between the conflicting parties and shepherd the process. This team should not include members of the government, any political parties affiliated with the government, the Taliban or opposition parties, nor Jihadi groups and commanders. The objective should be to create a process aiming to create institutions for sharing and dividing power among conflicting parties. This power-sharing framework would increase the prospects of building momentum toward an enduring peace.

\section{Notes}

* Abdul-Qayum Mohmand, Professor of Political Science and Middle East Studies at the University of Utah, where he took his $\mathrm{PhD}$ in Middle East Studies and Political Science. His area research includes international security and conflict studies, political violence and terrorism, Middle East government and politics, and Islamic political thought.

1. Mathew Hoh, "Letter of Resignation," available online at http://www.washingtonpost.com/wp-srv/ hp/ssi/wpc/ResignationLetter.pdf (accessed on 22 October 2012), 2.

2. Hoh, "Letter of Resignation", 2. 